\title{
Dual Roles for Endothelin-B Receptors in Modulating Adjuvant-Induced Inflammatory Hyperalgesia in Rats
}

\author{
Alla Khodorova ${ }^{1}$, Shiping $Z_{0 u}^{2}$, Ke Ren $^{2}$, Ronald Dubner ${ }^{2}$, Gudarz Davar ${ }^{1,3}$ and Gary Strichartz ${ }^{*, 1}$ \\ ${ }^{1}$ Pain Research Center, Department of Anesthesiology, Perioperative and Pain Medicine, Brigham and Women's \\ Hospital, Harvard Medical School, Boston, MA, and ${ }^{2}$ Department of Biomedical Sciences, Dental School, Program in \\ Neuroscience, University of Maryland, Baltimore, MD, USA \\ ${ }^{3}$ Current address: BiogIdec, Inc., 14 Cambridge Center, Cambridge, MA, USA
}

\begin{abstract}
Injection of endothelin-1 (ET-1) into the plantar rat hindpaw causes acute pain at high concentrations and tactile sensitization at low concentrations. The pro-nociceptive actions are driven through $\mathrm{ET}_{\mathrm{A}}$ receptors for both levels of [ET-1], but the $\mathrm{ET}_{\mathrm{B}}$ receptors are only pro-nociceptive for allodynia from low [ET-1] and anti-nociceptive for pain from high [ET-1]. The goal of the present work was to discriminate the roles of the ET receptors in the acute hyperalgesia from inflammation by complete Freund's adjuvant (CFA, $20 \mathrm{mg} / \mathrm{paw}$ ) into the rat hindpaw. Selective antagonists were injected 10 min before and then together with CFA. An $\mathrm{ET}_{\mathrm{A}}$ receptor antagonist, BQ-123, reduced CFA-induced thermal hyperalgesia (by up to 50\%), as did an $\mathrm{ET}_{\mathrm{B}}$ receptor antagonist, BQ-788 (by up to 66\%). BQ-123 and BQ-788 also delayed the onset (by $1.5-2 \mathrm{~h}$ ) but insignificantly reduced the maximum degree of CFA-induced allodynia $(\sim 10 \%)$. Surprisingly, an $\mathrm{ET}_{\mathrm{B}}$ receptor agonist, IRL-1620, also reduced maximum thermal hyperalgesia induced by CFA, suppressed peak allodynia and delayed its occurrence by $\sim 3 \mathrm{~h}$. The latter actions of IRL-1620 were reversed by coadministration of BQ-788, naloxone hydrochloride and the peripherally restricted opiate receptor antagonist naloxone methiodide, and by antiserum against $\beta$-endorphin. These findings demonstrate an important role for endogenous ET-1 in acute inflammatory pain and a dual action of $\mathrm{ET}_{\mathrm{B}}$ receptors, including a pro-algesic action along with the important activation of a local analgesic pathway, implying that at least two different $\mathrm{ET}_{\mathrm{B}}$ receptors contribute to modulation of inflammatory pain.
\end{abstract}

Keywords: Inflammatory hyperalgesia, endothelin-1, pro-nociception, anti-nociception, allodynia, pain.

\section{INTRODUCTION}

Inflammation releases substances that excite or sensitize primary afferent nerve fibers and cause pain and hyperalgesia [1,2]. Endothelin-1 (ET-1) is a peptide released following tissue injury and over-secreted in inflammatory conditions [3], and is derived from various cells in skin: keratinocytes [4], vascular endothelial cells [5], immune cells $[6,7]$ and mast cells [8]. Sensory afferents themselves [9-11] and satellite cells of DRG [12] contain ET-1. Thus, both cells of the skin and those that innervate it may release ET-1 in normal and pathological conditions, and thereby contribute to pain (see review, [13]).

ET-1 potentiates the pain from pro-inflammatory mediators, e.g., $\mathrm{PGE}_{2}[14]$ as well as pain-related activities of the capsaicin-heat-proton-activated receptor TRPV1, detected at the cellular [15-18] and at the whole animal, behavioral level [19].

Endothelin-1 can simultaneously activate both nociceptive and analgesic pathways, [20-32]. Although at first these opposing effects might be explained by the different actions of the two different $\mathrm{G}$ protein-coupled receptors for ET-1,

*Address correspondence to this author at the Pain Research Center/ BWH, 75 Francis Street, Boston, MA 02115-6110, USA; Tel: (617) 732-7802; Fax: (617) 730-2801; E-mail: gstrichz@zeus.bwh.harvard.edu called $\mathrm{ET}_{\mathrm{A}}$ and $\mathrm{ET}_{\mathrm{B}}$, the problem is more complex. Exogenous ET-1 evokes acute pain, [21, 24, 25, 33] and similarly enhances actions of other algogens, e.g. in experimental arthritic pain $[23,24,34,35]$, both via $\mathrm{ET}_{\mathrm{A}}$ receptors. In contrast, activation of $\mathrm{ET}_{\mathrm{B}}$ receptors has been shown to have both an antihyperalgesic/antinociceptive action [24, 26, 27] and a pro-algesic action, e.g., causing mechanical hyper-nociception in rats [30]. A major objective of this paper is to address the separate, opposing effects of the $\mathrm{ET}_{\mathrm{B}}$ receptor, in inflammatory hyperalgesia that involves endogenous ET-1.

Endogenously-released ET-1 mediates pain (in the inflamed knee) via both $\mathrm{ET}_{\mathrm{A}}$ and $\mathrm{ET}_{\mathrm{B}}$ receptors [35]. $\mathrm{ET}_{\mathrm{B}}$ receptors contribute positively to pain from intraperitoneal inflammation in mice $[21,36]$. Although both complete Freund's adjuvant (CFA) and carrageenan have been reported to provoke thermal hyperalgesia in mice solely via $\mathrm{ET}_{\mathrm{A}}$ receptors, mechanical hyperalgesia in mice is mediated by both $\mathrm{ET}_{\mathrm{A}}$ and $\mathrm{ET}_{\mathrm{B}}$ receptors [29]. Carrageenan injected into peripheral tissues is known to rapidly increase local and plasma ET-1 levels [37] and chronic constriction of the rat sciatic nerve causing thermal and mechanical hyperalgesia (due to a substantial contribution from local inflammation [38]), elevates both ET-1 and $\mathrm{ET}_{\mathrm{A}}$ receptors at the injury site [39]. The behavioral signs of this injury-induced pain are reversed by an $\mathrm{ET}_{\mathrm{A}}$ receptor antagonist. 
In summary, the $\mathrm{ET}_{\mathrm{A}}$ receptor appears always to promote inflammatory pain, but the role of $\mathrm{ET}_{\mathrm{B}}$ receptors is controversial and seems to depend on many factors: the procedure, the species, and the inflammatory state. Since we have previously shown an anti-hyperalgesic action of $\mathrm{ET}_{\mathrm{B}}$ receptors in the un-inflamed rat paw, in this work we sought to determine if $\mathrm{ET}_{\mathrm{B}}$ receptors were anti- or pro-algesic on the acute inflammatory pain induced by CFA in the rat paw. A preliminary report of these findings was presented at the 2003 meeting of the Society for Neuroscience*.

\section{MATERIALS AND METHODOLOGY}

All procedures used in these studies adhered to guidelines approved by the Institutional Animal Care and Use Committee of the University of Maryland Dental School and performed according to the ethical standards prescribed by the Committee for Research and Ethical Issues of the International Association for the Study of Pain. Experiments were performed on 144 adult (250-300 g), male SpragueDawley rats (Harlan, Indianapolis, IN). Rats were housed in cages (2-3 per cage) in a viral antibody-free facility on a $12 / 12 \mathrm{~h}$ light/dark cycle with food and water ad libitum. Prior to beginning experiments, animals were handled for 1-3 days to acclimate them to both the experimenters and the testing environment. Before measurements the rats were placed in a clear plastic chamber on a glass surface and allowed to acclimate for 15 - $30 \mathrm{~min}$.

\section{Drugs}

Complete Freund's adjuvant (CFA, Mycobacterium tuberculosis; Sigma-Aldrich, St. Louis, MO), used as the inflammatory agent, was suspended in an oil/saline $(1: 1)$ emulsion and administered at a final concentration of 0.5 $\mathrm{mg} / \mathrm{ml}$. All drugs were diluted in phosphate buffered saline (PBS, $\mathrm{pH}=7.4$, Invitrogen, Carlsbad, $\mathrm{CA}$ ) as stock solutions and stored at $+4^{\circ} \mathrm{C}$. Crude $\beta$-endorphin antiserum $(\mathrm{C}-55$, a gift of Dr. G. Mueller, Uniformed Services University of the Health Sciences, Bethesda, Maryland) was stored at $-20^{\circ} \mathrm{C}$. Prior to the experiment, stock aliquots were diluted with PBS or mixed with undiluted CFA $(1 \mathrm{mg} / \mathrm{ml})$ at $1: 1(\mathrm{v} / \mathrm{v})$. During experiments, working solutions were kept on ice to minimize breakdown. Crude C-55 was centrifuged for $5 \mathrm{~min}$ at $14,000 \mathrm{x} g$ in a microcentrifuge, then the supernatant was collected and used for injections. The $\mathrm{ET}_{\mathrm{A}}$ receptor selective antagonist, BQ-123 (D-Trp-D-Asp-Pro-D-Val-Leu), the ET $_{B}$ receptor selective antagonist, BQ-788 ( $N$-cis-2,6-Dimethylpiperidinocarbonyl-L-gamma-methylleucyl-D-1-thoxycarbonyltryptophanyl-D-Nle); and the $\mathrm{ET}_{\mathrm{B}}$ receptor selective agonist, IRL-1620 (Suc-Asp-Glu-Glu-Ala-Val-Tyr-Phe-AlaHis-Leu-Asp-lle-lle-Trp; were supplied by American Peptides Co. (Sunnyvale, CA). Naloxone hydrochloride and methyl-naloxone iodide were obtained from Sigma-Aldrich Chemical. The dose of naloxone used for local injection was based on previously described reports of efficacy in rat models of cutaneous pain $[26,40,41]$.

* Zou S, Ren K, Dubner R, Khodorova A, Davar G. Endothelin receptor mechanisms of adjuvant-induced hyperalgesia in rats. 2003 (Abstract No 588.15). In: Program of the Society for Neuroscience $33^{\text {rd }}$ Annual Meeting, November 8-12.

\section{Injection Procedures}

Injections of $40 \mu 1$ were delivered subcutaneously through a 28 gauge needle (regular bevel, $12.7 \mathrm{~mm}$ length, BD Medical) into the mid-plantar hindpaw, about $1 \mathrm{~cm}$ distal to the heel (for thermal testing), or into the lateral edge of the hindpaw (for mechanical testing). Only one paw per rat was injected and tests were completed on that paw and on the contralateral paw. Drugs were delivered with regard to the unilateral delivery of CFA as follows: An ET-1 receptor agonist or two antagonists, or naloxone, were injected twice, first pre-emptively (10 min before), and then, a few seconds before CFA. The latter delivery ("second injection", as noted in Results), given into the same hind paw site, was followed immediately by CFA $(20 \mu \mathrm{g} / \mathrm{paw})$, as the third injection. (These procedures are referred to as $C F A+$ agent in the Data Analysis section, below). In "control" experiments, the first two injections (prior to CFA) contained vehicle only (referred to as $C F A+$ vehicle). ET receptor agonist, antagonists, and opioid receptor antagonists, or antiserum to $\beta$-endorphin were always injected at the same concentration for both first and second injections. In several previous reports of these agents acting in the rat skin we have shown that these concentrations of agents appear to be selective and effective, although in all cases they had to be used at several orders of magnitude above their equilibrium dissociation constant values. Concerns about this large ratio are addressed in the Discussion.

\section{Thermal Nociceptive Testing}

The thermal nocifensive response was tested using the method of Hargreaves et al. [42], that allows for side-by-side comparisons of drug effects on inflamed and uninflamed paws within the same animal. The paw withdrawal latency, to the nearest $0.1 \mathrm{~s}$, in response to paw heating by radiant energy was determined. If a rat failed to withdraw the heated paw by $20 \mathrm{~s}$ (cut off value), the trial was terminated. Initially, withdrawal latencies were measured in both left and right, naïve paws (pre-CFA level). Then, $15 \mathrm{~min}$ after CFA administration testing re-started and continued three more times for the next $3 \mathrm{~h}$, and then daily for up to 3 days after injection.

\section{Responses to Mechanical Stimulation}

Calibrated Semmes-Weinstein (S-M) monofilaments (von Frey filaments, Stoelting, Wood Dale, IL) were used to mechanically stimulate the hindpaw. The bending force of the filaments ranged from 1 to $257 \mathrm{~g}$. The testing method has been described in detail previously [43, 44]. Briefly, rats were habituated to stand on their hindpaws and lean against the experimenter's hand covered by a regular leather work glove (Sears Inc., Balto, MD). The testing filament was pressed in the medial direction against the lateral edge of the hindpaw. The filaments were applied in an ascending series until the rat lifted the stimulated hindpaw. A descending series of the filaments were used when the rat responded to the starting filament. Each filament was tested 5 times, separated by intervals of a few seconds. If paw-withdrawal due to stimulation was observed, it was registered as a response to a filament. The response frequencies [(number of responses/number of stimuli) $\mathrm{X} 100 \%$ ] to a range of von 
Frey filament forces were determined and a stimulusresponse frequency curve was plotted. Non-linear regression analysis allowed determination of an $\mathrm{EF}_{50}$ value, defined as the von Frey filament force $(\mathrm{g})$ that produces a $50 \%$ response frequency and used as the measure of mechanical sensitivity. Prior to injection of CFA, there was no significant difference between the baseline stimulus-response frequency curves among the different groups of animals.

\section{Data Analysis}

Data are reported as means \pm S.E.M. Thermal hyperalgesia from CFA (preceded by 'control', vehicle injections, see p.8) was determined at the different times from the change from the baseline, pre-CFA value of the Paw Withdrawal Latency (PWL, in secs.). The degree of inhibition of the response by different doses of the different test agents was quantitated by taking the difference in the change in PWL between the $C F A+$ vehicle injection and the $C F A+$ agent injection, and dividing it by the change in PWLs between Baseline and CFA + vehicle:

$\%$ inhibition $=100 \times \frac{(\text { PWL: CFA }+ \text { agent })-(\text { PWL: CFA + vehicle })}{(\text { Baseline PWL })-(\text { PWL: CFA + vehicle })}$

To establish significant differences between the effects of $C F A+$ vehicle and $C F A+$ agent, multi-group ANOVA was performed with post-hoc application of Fisher's protected least significant difference test. $P<0.05$ was considered significant in all cases.

\section{RESULTS}

\section{General Observations of Inflammatory Pain}

Injection of CFA into the rat hindpaw produced a rapid onset of both thermal and mechanical hyperalgesia, as previously described [45, 46]. Within 15 min after CFA injection $(20 \mu \mathrm{g} / \mathrm{paw})$, the latency to paw withdrawal (PWL) in response to a noxious thermal stimulus was significantly reduced, and persisted so for at least $3 \mathrm{~h}$ (Fig. 1). About $25 \%$ recovery had occurred at day 1 and about $70 \%$ by day 3 , although thermal hypersensitivity was still significant at that time.

Single injections of the same volume $(40 \mu \mathrm{l})$ of phosphate buffered saline (PBS) into the paw caused no significant change in PWL. Three injections of this volume, with the same intervals between injections as those used for the delivery of antagonists before and with CFA (see next), caused $\sim 20 \%$ shortening in PWL $(P>0.05$ compared to baseline) at $15 \mathrm{~min}$ after the third injection, a reduction that slowly declined to zero over the next $90 \mathrm{~min}$. The fall in PWL induced by saline was unaffected by an $\mathrm{ET}_{\mathrm{A}}$ receptor antagonist, indicating that it was not due to ET-1 released by the needle puncture.

CFA-induced hyperalgesia was accompanied by erythema and swelling of the hindpaw, similar to that reported for CFA given at higher doses [46-48]. Licking and guarding behavior of the injected hindpaw were also observed, as previously described. No significant changes in thermal or mechano-responsiveness were detected in the

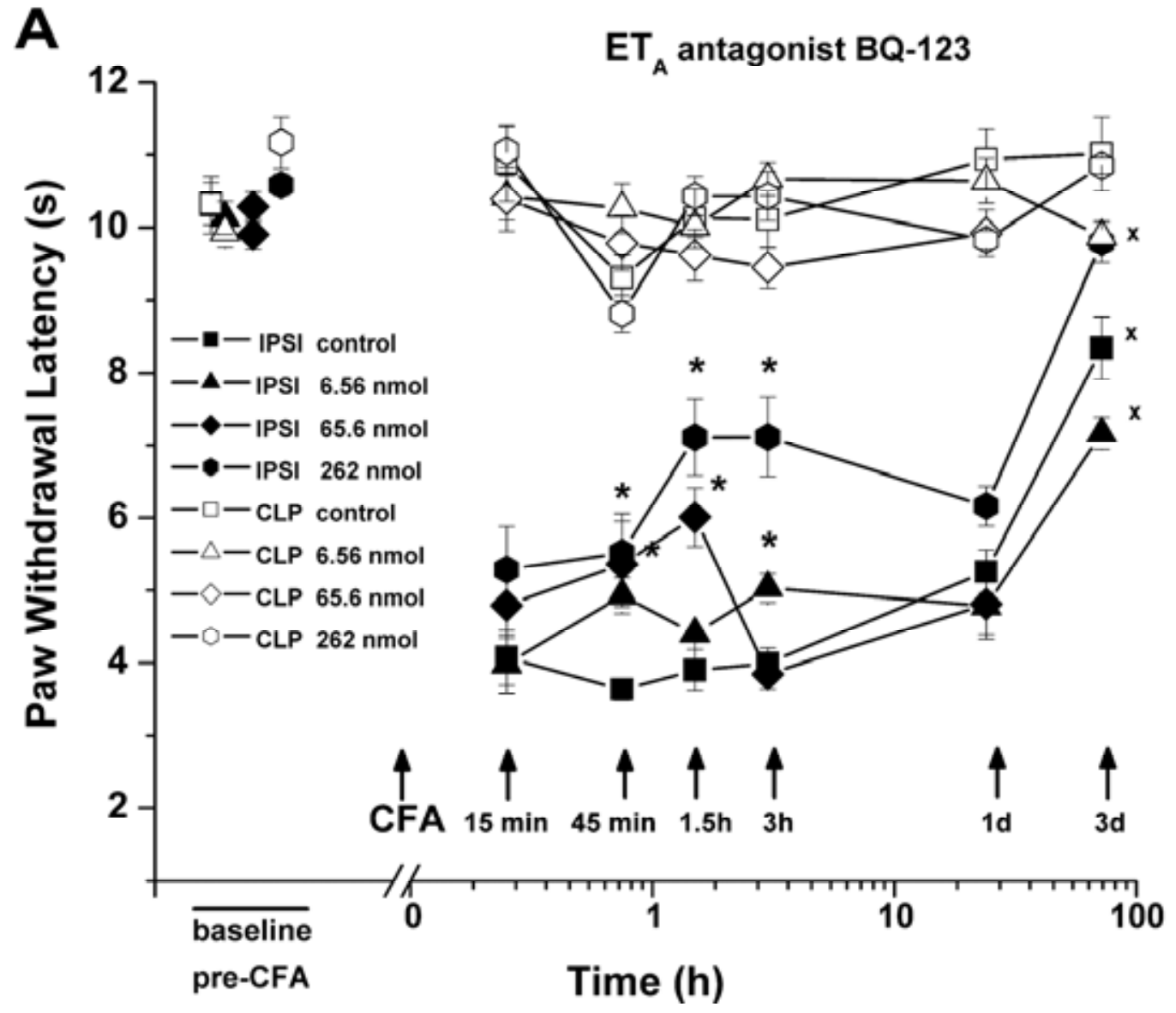


B

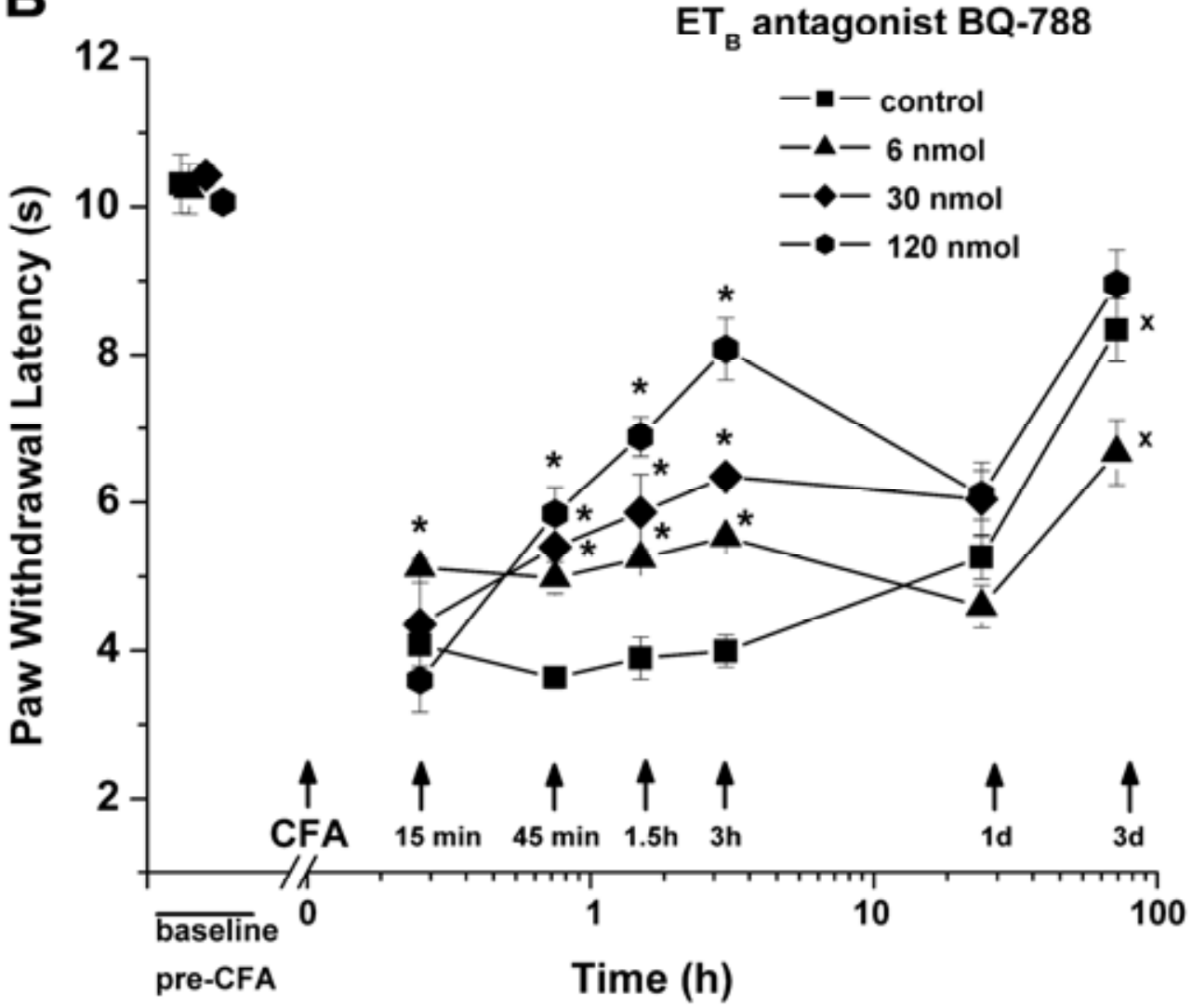

Fig. (1) Contd..... 


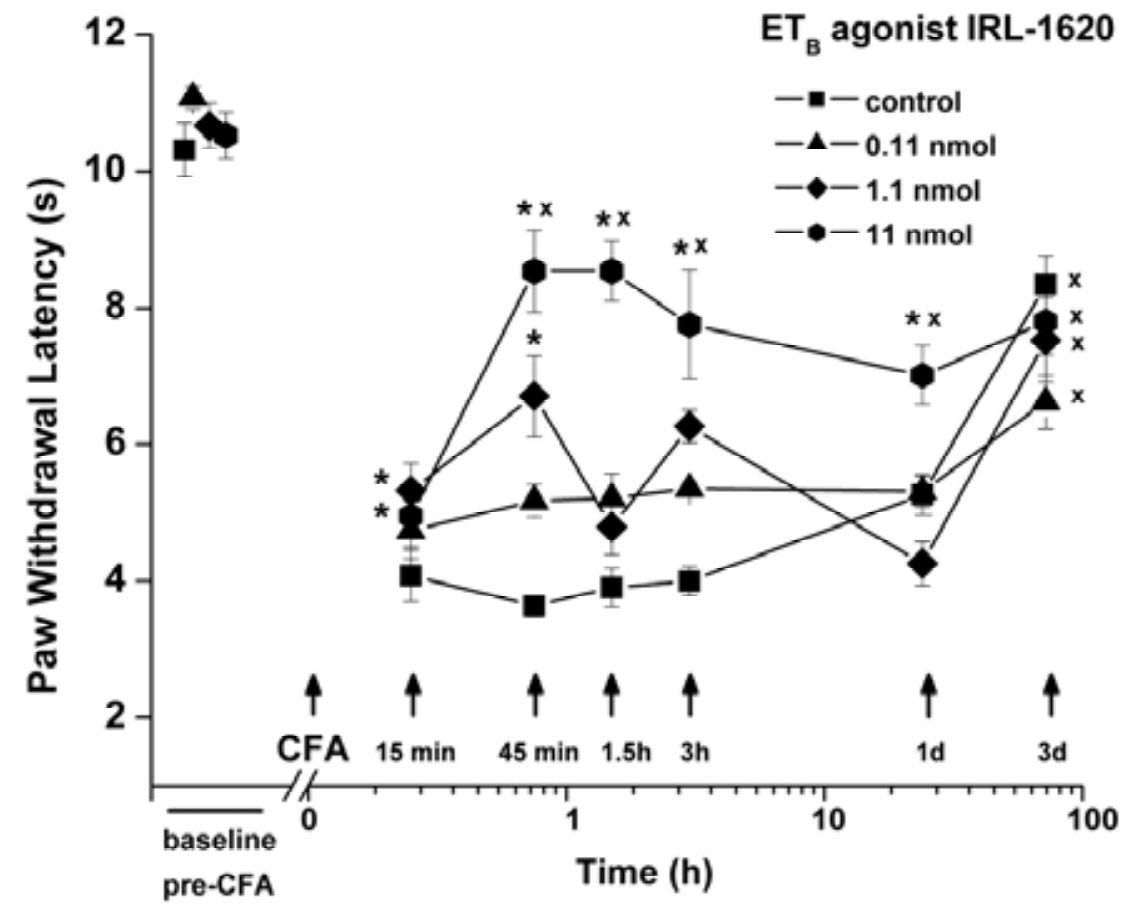

Fig. (2). Robust anti-hyperalgesic effect of IRL-1620. Inhibition of CFA-induced thermal hyperalgesia occurred when ipsilateral injection of the $\mathrm{ET}_{\mathrm{B}}$ agonist IRL-1620 preceeded CFA $(n=22) .{ }^{*} P<0.05$ indicates significant difference from control, CFA + vehicle $(n=11) ;{ }^{\mathrm{x}} P<0.05$ for comparison with baselinel (pre-CFA) values in the ipsilateral paw.

$n=4)$ (data not shown). This effect was half that resulting from the same concentration/dose injected directly into the paw and was equal to the effect when 0.1 of this total dose, i.e., 1.1 nmoles, was injected in the paw. It appears that a portion of the anti-hyperalgesic action of the $\mathrm{ET}_{\mathrm{B}}$ agonist resulted from its systemic distribution.
Concentration vs. response curves for the inhibition of CFA-induced thermal hyperalgesia by these antagonists of $\mathrm{ET}_{\mathrm{A}}$ and $\mathrm{ET}_{\mathrm{B}}$ receptors and the $\mathrm{ET}_{\mathrm{B}}$ receptor agonist IRL1620 are shown in Fig. (3). (Here the injected doses are expressed as injected concentrations to permit comparison with published $\mathrm{K}_{\mathrm{i}}$ values, reported as concentrations.) The

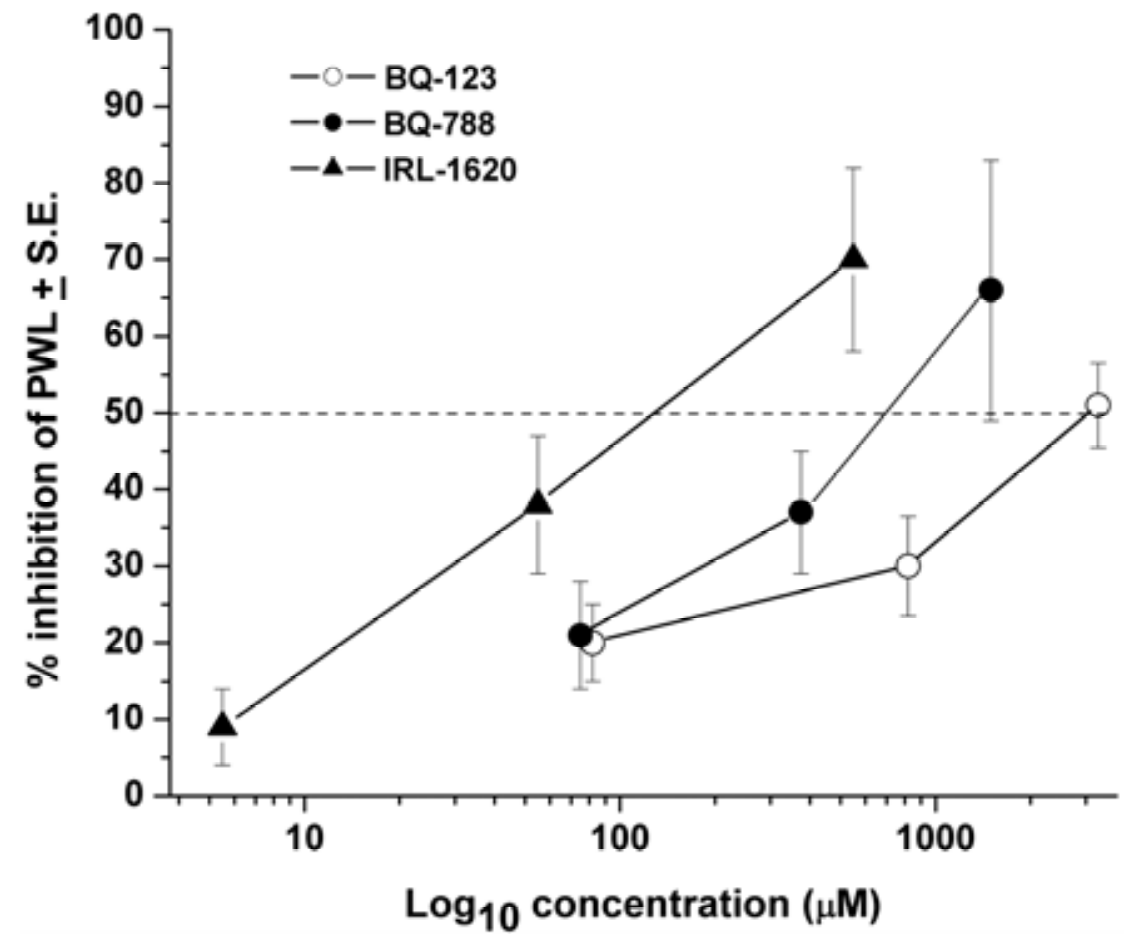

Fig. (3). Concentration vs inhibition of thermal hyperalgesia (shortening of paw withdrawal latency) by the antagonists of $\mathrm{ET}_{\mathrm{A}}$ and $\mathrm{ET}_{\mathrm{B}}$, and the agonist of $\mathrm{ET}_{\mathrm{B}}, \mathrm{BQ}-123$ and BQ-788, and IRL-1620, respectively. Intercepts of the dashed line indicate the EC50s. 
data are too sparse for serious fitting of a non-linear function, e.g. a Hill equation, but data points above and below the $50 \%$ inhibition line allow estimates of IC50 values. From such interpolation, the IC50s equal about 3 $\mathrm{mM}$ and $0.7 \mathrm{mM}$ for the respective antagonists, BQ-123 and BQ-788, and about $0.1 \mathrm{mM}$ for the agonist, IRL-1620. These values are in the same rank order as the reported affinities of these ligands for their respective receptors, a result that is consistent with the reported selectivity for the intended targets (see Discussion).

\section{IRL-1620-Induced Anti-Hyperalgesia Operates through ET $_{B}$ Receptors, is Naloxone-Sensitive and Mediated by $B$ - Endorphin}

To confirm that an $\mathrm{ET}_{\mathrm{B}}$ receptor mediates the observed anti-hyperalgesic actions of IRL-1620, we co-injected this agonist $(0.55 \mathrm{mM}$; total dose $11 \mathrm{nmol} / \mathrm{paw})$ together with the $\mathrm{ET}_{\mathrm{B}}$ receptor antagonist, $\mathrm{BQ}-788(0.75 \mathrm{mM}$; total dose 60 $\mathrm{nmol} / \mathrm{paw}$ ) before CFA. The peak anti-hyperalgesic action of IRL-1620 ( $\sim 75 \%$ inhibition of the shortening of PWL caused by CFA, at $45 \mathrm{~min}, n=12$ ) was reduced by about $2 / 3$ (to $\sim 24 \%, n=6$, inhibition) by BQ-788 (Fig. 4), close to the value from inhibition from the systemic delivery of this dose (see above). This effect on CFA-induced hyperalgesia is consistent with IRL-1620's specific binding to local $\mathrm{ET}_{\mathrm{B}}$ receptors to effect cutaneous anti-hyperalgesia, as we have shown previously for IRL-1620's effect on ET-1-induced pain behavior [26]. The residual anti-hyperalgesia when the local $\mathrm{ET}_{\mathrm{B}}$ antagonist was co-injected with the agonist suggests that this antagonist may not distribute systemically to the same extent at IRL-1620.

Antinociception from IRL-1620 against the pain from exogenous ET-1 in glabrous paw skin is mediated by $\beta$ endorphin that is locally released from keratinocytes and then bound to $\mu$-opioid receptors, most probably located on nociceptor terminals [27]. We hypothesized that $\beta$-endorphin also mediates IRL-1620's inhibitory actions on CFA-induced hyperalgesia. Indeed, antisera against $\beta$-endorphin $(\mathrm{C}-55$, $200 \mu \mathrm{g} / 10 \mu \mathrm{l}$ ) [49], injected subcutaneously into the plantar hindpaw 15 min before IRL-1620+CFA, almost completely prevented the inhibitory actions of IRL-1620, ( 75\% suppression by IRL-1620 alone, compared to $\sim 12 \%$ suppression for IRL-1620 in C-55 pre-treated paws, $n=6 ; P<0.005$; Fig. 4). Naive rabbit serum (NRS), lacking antibodies against $\beta$ endorphin, did not affect IRL-1620's anti-hyperalgesia ( $n=4$; Fig. 4).

To verify that IRL-1620's inhibitory actions on CFAinduced hyperalgesia are mediated by opioid receptors, we used the opioid receptor antagonist naloxone ((-)-naloxone hydrochloride, NX). Co-injection of NX $(0.69 \mathrm{mM}$; total dose $55 \mathrm{nmol} / \mathrm{paw}$ ) with IRL-1620 lessened the inhibition of CFA-induced hyperalgesia, (Fig. 4; 42\% inhibition at 45 min; $n=6$, compared to $\sim 75 \%$ inhibition by IRL- 1620 alone before CFA; $P<0.05)$.

In order to separate the peripheral and central nervous system effects of NX, we co-injected a peripherallyrestricted opioid receptor antagonist, methyl-naloxone iodide

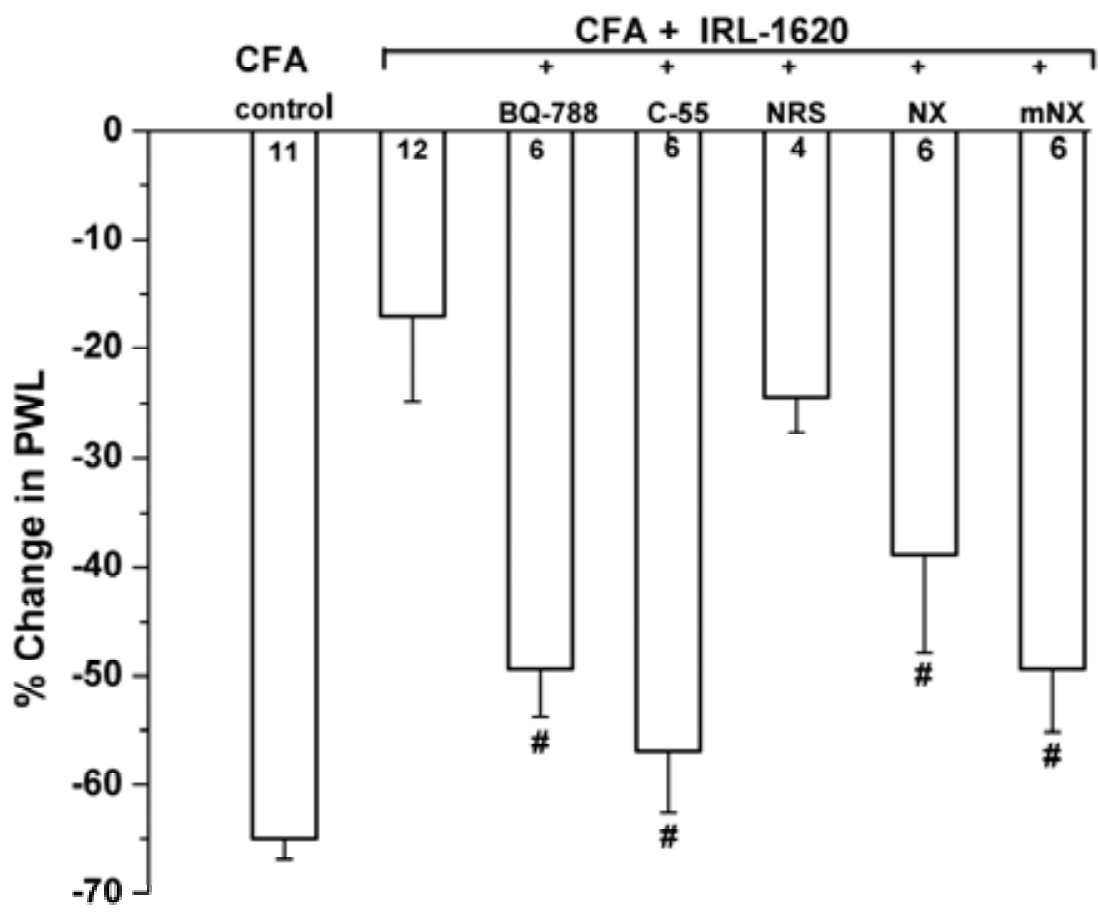

Fig. (4). Modulation of IRL-1620's anti-hyperalgesic action. The vertical axis shows the percent change, due to local injection of IRL-1620 (total dose $11 \mathrm{nmol} / \mathrm{paw}$ ), in the paw withdrawal latency caused by CFA injection, calculated as: [(post-CFA: PWL - pre-CFA: PWL) / preCFA: PWL] x 100\%, where a negative value results from reduction of PWL, indicative of hyperalgesia. Data show the peak values at 45 min time point. The inhibitory effect of co-administered, local IRL-1620 on CFA-induced thermal hyperalgesia is ET $_{\mathrm{B}}$-receptor mediated (restored by BQ-788), naloxone (NX)- and naloxone methiodide (mNX)-sensitive, is prevented by antisera against $\beta$-endorphin (C55, $200 \mu \mathrm{g}$ in $10 \mu \mathrm{l}$ ), but not naïve anti-serum (NRS). ${ }^{\sharp} P<0.05$ indicates significant differences from IRL-1620; the number of experiments is indicated in the corresponding column. 
(mNX, $0.69 \mathrm{mM}$; total dose $55 \mathrm{nmol} / \mathrm{paw}$ ). This antagonist also substantially prevented IRL-1620's anti-hyperalgesia (from $\sim 75 \%$ inhibition of the CFA-induced shortening in PWL by IRL-1620 alone $v s$. $\sim 25 \%$ inhibition with $\mathrm{mNX}+$ IRL-1620, $n=6, P<0.005$; Fig. 4). To control for possible systemic actions of $\mathrm{mNX}$, it was injected subcutaneously at the neck with the same total dose as injected into the paw prior to injection of IRL-1620+CFA into the hindpaw. This treatment resulted in a weak and insignificant reduction of the anti-hyperalgesic actions of local IRL-1620 (from $~ 75 \%$ to $\sim 51 \%, n=4$, change in PWL, $P>0.05$ ) (data not shown).

\section{Blockade of $\mathbf{E T}_{\mathrm{A}}$ and $\mathbf{E T}_{\mathrm{B}}$ Receptors Inhibits Mechanical Hyperalgesia Evoked by CFA}

Mechanical hypersensitivity following CFA administration into the lateral edge of the rat hindpaw was characterized by both an increase in responses to supra-threshold stimuli (mechanical hyperalgesia) and the appearance of responses to weak stimuli that in naive animals did not produce nocifensive behavior (tactile allodynia). These changes, together causing a drop in the $\mathrm{EF}_{50}$ for paw withdrawal, were apparent within $15 \mathrm{~min}$ after injection, continued to increase up to $3 \mathrm{~h}$, were maintained to day 1 , and had partially recovered by day 3 (Fig. 5).
In the inflamed paw there is at least a 10-fold increase in mechanical sensitivity, evident when $\mathrm{EF}_{50}=10 \mathrm{~g}$ at $15 \mathrm{~min}$ after CFA, and which continues to fall over $3 \mathrm{hrs}$ (to $\sim 3 \mathrm{~g}$ ). This substantial mechanical hypersensitivity is sustained for 1 day, with partial recovery at 3 days. When the $\mathrm{ET}_{\mathrm{A}}$ receptor is blocked by $\mathrm{BQ}-123(0.82 \mathrm{mM}$; total dose 66 $\mathrm{nmol} / \mathrm{paw}$ ) injected subcutaneously into the lateral edge of the rat hindpaw before CFA, the occurrence of mechanical hyperalgesia was delayed by several hours $(n=6$; Fig. 5). However, BQ-123 did not significantly elevate the maximum $\mathrm{CFA}$-altered reduction in $\mathrm{EF}_{50}$ measured from $3 \mathrm{~h}$ until day 3. Neither injection of CFA alone nor of BQ-123 + CFA affected responses to mechanical stimulation of the contralateral paw (not shown).

Blockade of $\mathrm{ET}_{\mathrm{B}}$ receptors by $\mathrm{BQ}-788(0.75 \mathrm{mM}$; total dose $60 \mathrm{nmol} / \mathrm{paw}$ ), injected before CFA, had a similar effect, delaying the development of mechanical hyperalgesia, with significant differences from CFA (after vehicle) at 15 and $45 \mathrm{~min}$, but not effecting the $\mathrm{EF}_{50} \mathrm{~S}$ at later times $(n=4$; Fig. 5). The inhibition, by BQ-788, was briefer (maximum at $45 \mathrm{~min} v s .90 \mathrm{~min})$, and significantly smaller $(P<0.001)$ at 45 min after CFA, than the inhibition by almost equimolar $(0.82$ $\mathrm{mM}$, from 66 nmoles) BQ-123, showing a potency rank of BQ-123>BQ-788, in contrast to the ca. 3-fold greater molar potency of BQ-788 over BQ-123 in suppressing thermal

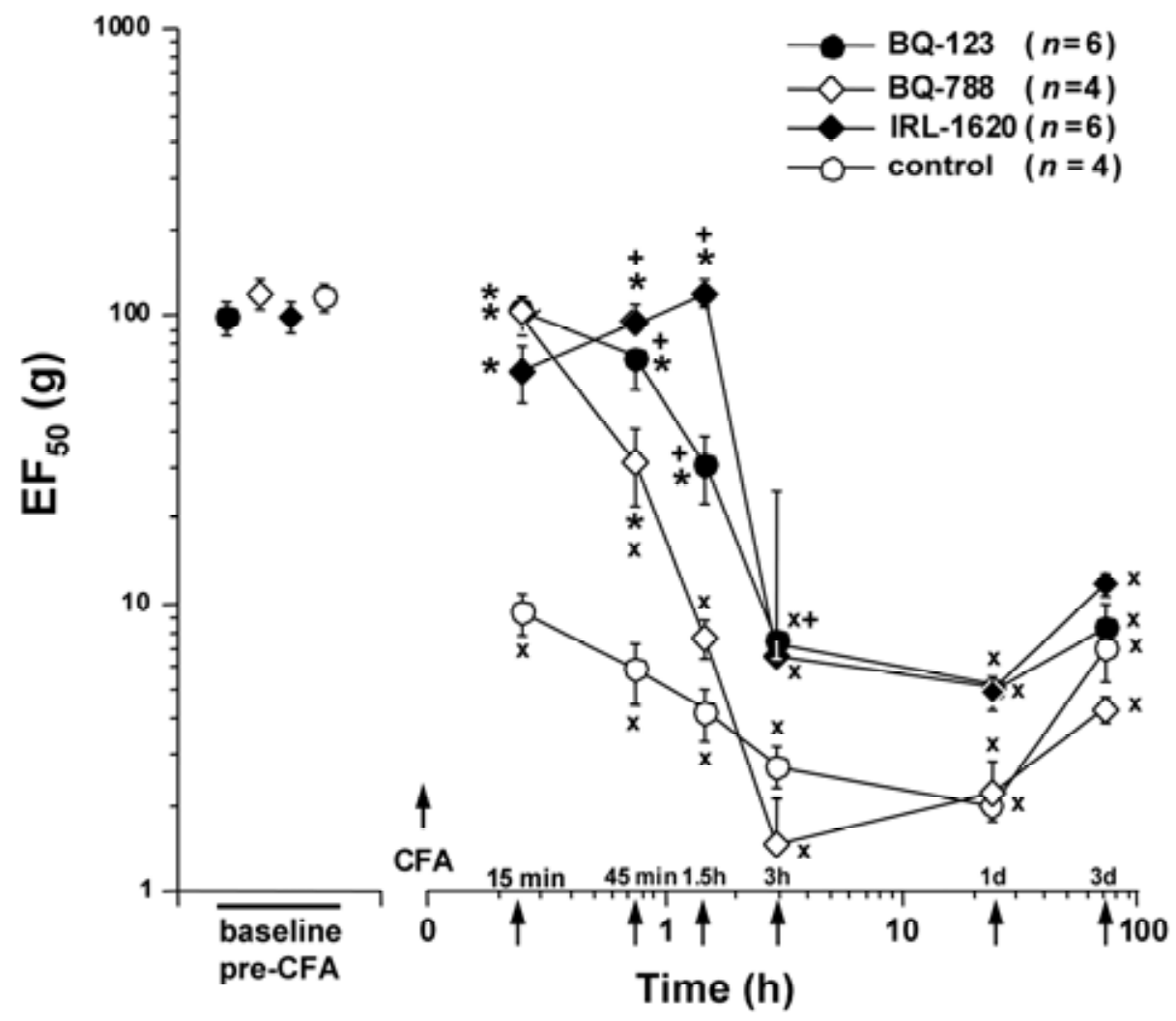

Fig. (5). Effects of the selective ET-receptor antagonists and $\mathrm{ET}_{\mathrm{B}}$ agonist on tactile hyperesthesia. $\mathrm{EF}_{50} \mathrm{~s}$, defined as the von Frey filament force $(\mathrm{g})$ that produces withdrawal response half the time, were determined from interpolation of stimulus-response functions and used as a measure of mechanical sensitivity. Local pre-treatment (10 min prior to CFA and at the time of CFA injection) of rats with BQ-123 (total dose $65.6 \mathrm{nmol} / \mathrm{paw}$ ), or BQ-788 (total dose $60 \mathrm{nmol} / \mathrm{paw}$ ) delayed the fall of $\mathrm{EF}_{50}$ in the inflamed paw, when compared to $\mathrm{CFA}+\mathrm{vehicle}$ treated rats. Pre-treatment with the $\mathrm{ET}_{\mathrm{B}}$ agonist IRL-1620 (total dose $11 \mathrm{nmol} / \mathrm{paw}$ ) prevented mechano-allodynia for $1.5 \mathrm{~h}$. From $3 \mathrm{~h}$ onward there was no difference in $\mathrm{EF}_{50} \mathrm{~s}$ between any of the ET-receptor agent-treated rats and those receiving CFA alone. $(* P<0.05$ indicates significant differences from controls (CFA injection 10 min after vehicle injection). ${ }^{\mathrm{x}} P<0.001$ for CFA + vehicle or CFA + antagonist/agonist $v s$. the baseline, pre-CFA, values. ${ }^{+} P<0.05$ for BQ-123 + CFA or IRL-1620 + CFA vs. BQ-788 + CFA). 
hyperalgesia (Fig. 3, above). BQ-788 treatment did not affect the mechanical responsiveness of the contralateral paw (not shown).

\section{Activation of an $\mathbf{E T}_{\mathrm{B}}$ Receptor Suppresses Mechanical Hyperalgesia Evoked by CFA}

To assess the ability of $\mathrm{ET}_{\mathrm{B}}$ receptor activation to inhibit CFA-evoked mechanical hyperalgesia, IRL-1620 (total dose $11 \mathrm{nmol} / \mathrm{paw})$ was injected before CFA $(n=6)$. IRL-1620 prevented any decrease in $\mathrm{EF}_{50}$ from CFA for the first 90 min (Fig. 5). However, subsequent mechanical responses measured $3 \mathrm{~h}$ and longer after injection of $I R L-1620+C F A$, were not different from vehicle $+C F A$ controls.

\section{DISCUSSION}

The results reported here show that acute thermal and mechanical hyperalgesia, from inflammation induced by subcutaneous CFA in the rat hind paw, were inhibited by blockade of both local $\mathrm{ET}_{\mathrm{A}}$ and $\mathrm{ET}_{\mathrm{B}}$ receptors. In addition, activation of an $\mathrm{ET}_{\mathrm{B}}$ receptor also strongly reduced thermal and mechanical hyperalgesia. This latter anti-hyperalgesic effect was shown to be naloxone-sensitive and is probably dependent on keratinocyte release of the endogenous opioid peptide, $\beta$-endorphin [27]. Although a minor portion of the anti-hyperalgesic effect of the $\mathrm{ET}_{\mathrm{B}}$ antagonist, was due to systemic effects, about $75 \%$ was attributable to local actions in the paw.

It is essential to establish the receptor specificity of the ET receptor ligands used here. In other in vivo studies, conducted in our laboratory, measuring behavior or electrophysiological responses, high concentrations were used with total abolition of pain responses to ET-1 by BQ123 and total reversal of $\mathrm{ET}_{\mathrm{B}}$-mediated analgesia by BQ-788 [25-27, 50]. Despite these high concentrations, the rank order of potency, IRL-1620> BQ-788 BQ-123, in the present study is the same as the published in vitro inhibitory potencies for the respective ET receptor: $\mathrm{K}_{\mathrm{i}}=16 \mathrm{pM}$ for IRL-1620 at $\mathrm{ET}_{\mathrm{B}}$ receptors [51], $\mathrm{K}_{\mathrm{i}}=1-100 \mathrm{nM}$ for $\mathrm{BQ}-788$ at $\mathrm{ET}_{\mathrm{B}}$ receptors $[52,53]$ and $\mathrm{K}_{\mathrm{i}}=3.3-22 \mathrm{nM}$ for $\mathrm{BQ}-123$ at $\mathrm{ET}_{\mathrm{A}}$ receptors [54-56].

In every report of ET-1-related effects, $\mathrm{ET}_{\mathrm{A}}$ receptor activation is pro-algesic, consistent with the observed inhibitory effect of the $\mathrm{ET}_{\mathrm{A}}$ receptor antagonist $\mathrm{BQ}-123$ on CFA-induced hyperalgesia [13]. Activation of an $\mathrm{ET}_{\mathrm{B}}$ receptor by subcutaneous IRL-1620 has been shown previously to suppress nociception, and with the same apparent dependence on an opioidergic pathway as shown here. There is a hypothetical possibility that IR-1620 might also act on $\mathrm{ET}_{\mathrm{A}}$ receptors $\left(\mathrm{K}_{\mathrm{i}}=1.9 \mu \mathrm{M}\right.$ for $\mathrm{ET}_{\mathrm{A}}$; [51]), however, in the case of $\mathrm{ET}_{\mathrm{A}}$ activation such an effect would favor hyperalgesia, not inhibit it. The fact that IRL-1620's anti-hyperalgesic effect is reversed by an $\mathrm{ET}_{\mathrm{B}}$ receptor antagonist, and by naloxone and the $\beta$-endorphin antibody, is completely inconsistent with $\mathrm{ET}_{\mathrm{A}}$ receptor blockade. The specificity of BQ-788 for inhibition of $\mathrm{ET}_{\mathrm{B}}$ receptors is testified to by its ability to abolish the analgesia from IRL1620 , whereas if it were acting at $\mathrm{ET}_{\mathrm{A}}$ receptors its effect would be anti-hyperalgesic. The reported effects are therefore fully consistent with the proposed specificity. It seems likely that the requirement for the high concentrations of subcutaneously administered agents results from the relatively impermeant nature of the dermis to such molecules when they are delivered subcutaneously, coupled with the requirement to reach nerve endings and keratinocytes located in the epidermis in order to act. In addition, these antagonists are peptides that are proteolytically degraded in vivo, with half-lives of one hour or so [57], a factor that will determine not only the effective concentration that can reach the epidermal compartment but also the duration profile for the agents, possibly contributing to the $<1$ day period of effective inhibition (cf. Fig. 1).

\section{Endogenous ET-1 and ET-Receptors in Adjuvant- Induced Thermal Hyperalgesia}

The $\mathrm{ET}_{\mathrm{A}}$ receptor antagonist $\mathrm{BQ}-123$ significantly relieved thermal hyperalgesia in CFA-treated rats, implying that endogenously released ET-1 causes part of this elevated pain response to CFA. Administered within the range of concentrations previously shown to completely abolish pain behavior evoked by exogenous ET-1 in rats $[25,50]$, BQ123 nonetheless only inhibited thermal hyperalgesia from CFA by $\sim 50 \%$. This inhibition reached its maximum at $45-$ 90 min after CFA, consistent with the time course of stimulation-induced ET-1 production in different tissues in vivo (see [3]). The results with BQ-123 in the present study are evidence of an important, but limited role of $\mathrm{ET}_{\mathrm{A}}$ receptors in endogenous ET-1's actions in CFA-induced thermal hyperalgesia in rats.

Previous work has shown physiological effects of $\mathrm{ET}_{\mathrm{A}}$ receptor activation, on the soma of sensory neurons in vitro $[58,59]$ and on impulses of nociceptive axons recorded in vivo after delivery of ET-1 to the plantar footpad (or to the sciatic nerve) [25, 50]. Physiological actions of ET-1 applied to bare nerve cells in vitro or ensheathed fibers in vivo, both purely $\mathrm{ET}_{\mathrm{A}}$ mediated effects, have been previously proposed to completely account for the generation of impulses by endogenous ET-1 in the skin, e.g. after an incision [22]. In agreement with this proposition, Baamonde et al. [29] reported that only antagonists of $\mathrm{ET}_{\mathrm{A}}$ receptors were able to attenuate thermal inflammatory hyperalgesia in mice. However, the current results, showing that a selective $\mathrm{ET}_{\mathrm{B}}$ receptor antagonist partially decreases inflammatory hyperalgesia in rats, suggests that both $\mathrm{ET}_{\mathrm{B}}$ and $\mathrm{ET}_{\mathrm{A}}$ receptors contribute to inflammatory hyperalgesia. Moreover, the role of $\mathrm{ET}_{\mathrm{B}}$ receptors in CFA-induced hyperalgesia in rats is even more complex, as shown by the anti-hyperalgesia caused by $\mathrm{ET}_{\mathrm{B}}$ receptor activation (see Dual effects from $\mathbf{E T}_{\mathbf{B}}$ receptors, below).

\section{Endogenous ET-1 and ET-Receptors in Inflammatory Mechanical Hyperalgesia}

Local blockade of either $\mathrm{ET}_{\mathrm{A}}$ or $\mathrm{ET}_{\mathrm{B}}$ receptors delayed the development of acute mechanical allodynia induced by CFA (Fig. 5). In contrast to the inhibitory actions on thermal hyperalgesia, the maximum extent of mechanical hyperalgesia was not affected by these agents, only the progression was slowed. Furthermore, at a time after CFA injection (45 min) when thermal hyperalgesia was only partially suppressed by BQ-123 (Fig. 1A) or BQ-788 (Fig. 
1B), the same concentrations/doses of these antagonists almost totally prevented tactile allodynia (Fig. 5). Mechanisms involving ET-1 pathways therefore may be more important for suppressing the earlier phases of tactile mechanical hyperalgesia, but play a more constant role throughout all the stages of thermal hyperalgesia. Whether this difference is due to differences in the location of CFA injections in these two sensory modes, or to a differential distribution of endothelin receptors on the respective fiber types coding these separate modalities [60-62], i.e., to a peripheral differentiation, or to different central processing by spinal units that discriminate between inputs from fibers activated by different modality sensations, i.e., to CNS differentiation [63], remains to be shown.

\section{Dual Effects from ET $_{B}$ Receptors: a Plurality of Func- tions}

The most remarkable observation here is that both an $\mathrm{ET}_{\mathrm{B}}$ receptor agonist and an $\mathrm{ET}_{\mathrm{B}}$ receptor antagonist reduced inflammatory thermal and mechanical hyperalgesia. These results indicate that under the conditions of acute inflammation $\mathrm{ET}_{\mathrm{B}}$ receptors are able to simultaneously mediate both pro- and anti-nociceptive actions.

The anti-hyperalgesia caused here by the $\mathrm{ET}_{\mathrm{B}}$ receptor antagonist BQ-788 agrees with previous reports that implicate $\mathrm{ET}_{\mathrm{B}}$ receptors in, 1. the pathogenesis of mechanosensitivity in inflammatory pain $[29,35]$, and with 2 . the observations that $\mathrm{ET}_{\mathrm{B}}$ receptors (together with $\mathrm{ET}_{\mathrm{A}}$ receptors) mediate mechanical hyperalgesia induced by relatively low concentrations (30 $\mathrm{nM} \mathrm{-} \mathrm{micromolar)} \mathrm{of}$ exogenous ET-1 [19, 29, 30, 64]. These anti-hyperalgesic effects of BQ-788, however, contrast sharply with the proalgesic actions of BQ-788 shown for responses to high exogenous ET-1, responses that include the exacerbation by ET-1 of capsaicin-stimulated paw licking in mice [24] and the hindpaw flinching induced by ET-1 in rats [26]

On the other hand, the anti-hyperalgesic actions of an agonist of $\mathrm{ET}_{\mathrm{B}}$ receptors, here seen for CFA-induced hyperalgesia, has also been reported for other tests. The agonist IRL-1620, given pre-emptively, strongly inhibited the acute nociception from ET-1 [26, 27], diminished the carrageenan-evoked hyper-nociception in the rat knee joint and reversed the increase in incapacitation caused by algogens delivered there [31]. Moreover, $\mathrm{ET}_{\mathrm{B}}$ receptor blockade enhanced both spontaneous and movement-evoked pain in a model of murine osteolytic cancer pain [65].

What might explain the similar effects from antagonists and agonists of $\mathrm{ET}_{\mathrm{B}}$ receptors? One possibility is that there are different sub-types of $\mathrm{ET}_{\mathrm{B}}$ receptors, with the one isoform blocked supporting pain, and another isoform suppressing pain. The particular contribution of $\mathrm{ET}_{\mathrm{B}}$ receptors, which may include more than one functional type $[3,66-68]$, to pain processing could depend on the conditions, e.g. whether the periphery is normal or inflamed, implying that certain inflammatory mediators can modify the expression of ET receptors, or the receptors/channels to which they couple, e.g., TRPV1 [16], to enhance both primary receptor activation and the downstream coupling pathways. Evidence in support of different functional types of the $\mathrm{ET}_{\mathrm{B}}$ receptor is found in the description of at least two types of $\mathrm{ET}_{\mathrm{B}}$ receptors, characterized by nanomolar and picomolar $\mathrm{K}_{\mathrm{D}}$ values for ET-1, that are involved in the G-protein-mediated activation of different signal transduction pathways in different tissues/cells (see [68]). An equally attractive alternative to requiring more than one $\mathrm{ET}_{\mathrm{B}}$ receptor subtype to explain these opposing effects is to have the same receptor located on different cell types, whose separate outputs have opposing effects on pain. For example, pro-nociceptive $\mathrm{ET}_{\mathrm{B}} \mathrm{S}$ might be present on nociceptors and sensitize them to the local excitatory actions of ET-1 acting through $\mathrm{ET}_{\mathrm{A}}$ and to excitation by noxious stimulation [19, 29], while anti-hyperalgesic $\mathrm{ET}_{B}$ would be present on keratinocytes where their activation triggers a widespread release of potent opioid peptides from these cells, e.g., $\beta$ endorphin, acting directly on nociceptive fibers and effecting a more powerful anti-hyperalgesic action. In fact, a very recent paper reports the presence of $\mathrm{ET}_{\mathrm{B}}$ receptors on the cell bodies of sensory neurons of the rat trigeminal ganglion, along with pharmacological data that such receptors contribute to nerve injury-induced thermal hyperalgesia [69].

\section{CONCLUSION}

In summary, we have shown that endogenous ET-1 plays an important role in thermal and mechanical hyperalgesia during acute inflammation. Both types of ET receptors mediate these hyperalgesic responses, and whereas $\mathrm{ET}_{\mathrm{A}}$ regulates only pro-nociceptive actions, activation of $\mathrm{ET}_{\mathrm{B}}$ appears to play a dual role in modulating the final magnitude of pathological hypersensitivity. Activation of $\mathrm{ET}_{\mathrm{B}}$ receptors was highly effective in suppressing thermal and delaying the development of mechanical hyperalgesia of inflammatory origin, implying that ET receptors act differently to induce these different forms of inflammatory hyperalgesia.

\section{ACKNOWLEDGEMENTS}

Thanks to Mr. Jamie Bell for technical assistance with the figures. Supported by USPHS grants CA080153 (to GS), DE1 1964 (to KR) and NS41384 (to RD).
ABBREVIATIONS
$\mathrm{CFA}=$ Complete Freund's adjuvant
ET-1 = Endothelin-1
$\mathrm{ET}_{\mathrm{A}}=$ Endothelin receptor- $\mathrm{A}$
$\mathrm{ET}_{\mathrm{B}}=$ Endothelin receptor- $\mathrm{B}$
$\mathrm{NX}=$ Naloxone
$\mathrm{mNX}=$ Methyl-naloxone
PBS = Phosphate buffered saline
PWL = Paw withdrawal latency
Veh $=$ Vehicle
$\mathrm{NRS}=$ Naïve rabbit serum
$\mathrm{EF}_{50}=$ Force $(\mathrm{g})$ that produces a $50 \%$ withdrawal response frequency 


\section{REFERENCES}

[1] Kidd BL, Urban LA. Mechanisms of inflammatory pain. Br J Anesthesiol 2001; 87: 3-11.

[2] Schaible HG, Ebersberger A, Von Banchet GS. Mechanisms of pain in arthritis. Ann NY Acad Sci 2002; 966: 343-54.

[3] Rae GA, Henriques MG. Endothelins in inflammation. In: Said S, Ed. Pro-inflammatory and Anti-inflammatory Peptides. New York: Marcel and Dekker 1998; pp. 163-202.

[4] Tsuboi R, Sato C, Shi CM, Nakamura T, Sakurai T, Ogawa H. Endothelin-1 acts as an autocrine growth factor for normal human keratinocytes. J Cell Physiol 1994; 159: 213-20.

[5] Yanagisawa M, Kurihara H, Kimura S, Goto K, Masaki T. A novel peptide vasoconstrictor, endothelin, is produced by vascular endothelium and modulates smooth muscle $\mathrm{Ca} 2+$ channels. J Hypertens Suppl 1988; 6: S188-91.

[6] Ehrenreich H, Anderson RW, Fox CH, et al. Endothelins, peptides with potent vasoactive properties, are produced by human macrophages. J Exp Med 1990; 172: 1741-48.

[7] Sessa WC, Kaw S, Hecker M, Vane JR. The biosynthesis of endothelin-1 by human polymorphonuclear leukocytes. Biochem Biophys Res Commun 1991; 174: 613-18.

[8] Ehrenreich H, Burd PR, Rottem M, et al. Endothelins belong to the assortment of mast cell-derived and mast cell-bound cytokines. New Biol 1992; 4: 147-56.

[9] Szolcsanyi J, Oroszi G, Nemeth J, Szilvassy Z, Blasig IE, Tosaki A. Functional and biochemical evidence for capsaicin-induced neural endothelin release in isolated working rat heart. Eur $\mathbf{J}$ Pharmacol 2001; 419: 215-21.

[10] Giaid A, Gibson SJ, Ibrahim BN, et al. Endothelin 1, an endothelium-derived peptide, is expressed in neurons of the human spinal cord and dorsal root ganglia. Proc Natl Acad Sci USA 1989; 86: 7634-38.

[11] Franco-Cereceda A, Rydh M, Lou YP, Dalsgaard CJ, Lundberg JM. Endothelin as a putative sensory neuropeptide in the guineapig: different properties in comparison with calcitonin gene-related peptide. Regul Pept 1991; 32: 253-65.

[12] Kar S, Chabot JG, Quirion R. Quantitative autoradiographic localisation of [125I]- endothelin-1 binding sites in spinal cord and dorsal root ganglia of the rat. Neurosci Lett 1991; 133: 117-20.

[13] Khodorova A, Montmayeur J-P, Strichartz G. Endothelin receptors and pain. J Pain 2009; 10: 4-28.

[14] Ferreira SH, Romitelli M, de Nucci G. Endothelin-1 participation in overt and inflammatory pain. J Cardiovasc Pharmacol 1989; 13 (Suppl 5): S220-22.

[15] Dymshitz J, Vasko MR. Endothelin-1 enhances capsaicin-induced peptide release and cGMP accumulation in cultures of rat sensory neurons. Neurosci Lett 1994; 167: 128-32.

[16] Yamamoto H, Kawamata T, Ninomiya T, Omote K, Namiki A. Endothelin-1 enhances capsaicin-evoked intracellular $\mathrm{Ca}+2$ response via activation of endothelin a receptors in aprotein kines $\mathrm{C}$ epsilon-dependent manner in dorsal root ganglion neurons. Neuroscience 2006; 137: 949-60.

[17] Plant TD, Zollner C, Mousa SA, Oschke A. Endothelin-1 potentiates capsaicin- induced TRPV1 currents via the endothelin A receptor. Exp Biol Med 2006; 231: 1161-4.

[18] Plant TD, Zollner C, Kepura F, Mousa SS, Eichhorst J, Schaefer M. Endothelin potentiates TRPV1 via ETA receptor-mediated activation of protein kinase C. Mol Pain 2006; 3: 35-42.

[19] Balonov K, Khodorova A, Strichartz G. Tactile allodynia initiated by local subcutaneous endothelin-1 is prolonged by activation of TRPV1 receptors. Exp Biol Med (Maywood) 2006; 231: 1165-70.

[20] Rubanyi GM, Polokoff A. Endothelins: molecular biology, biochemistry, pharmacology, physiology, and pathophysiology. Pharmacol Rev 1994; 48: 325- 415.

[21] Raffa R, Schupsky J, Jacoby H. Endothelin-induced nociception in mice: mediation by ETA and ETB Receptors. J Pharmacol Exp Ther 1996; 276: 647- 51.

[22] Mujenda FH, Duarte AM, Reilly EK, Strichartz GR. Cutaneous endothelin-A receptors elevate post-incisional pain. Pain 2007; 133: 161-73.

[23] Piovezan AP, D'Orleans-Juste P, Tonussi CR, Rae GA. Effect of endothelin-1 on capsaicin-induced nociceptive in mice. Eur $\mathbf{J}$ Pharmacol 1998; 351: 15-22.

[24] Piovezan, AP, D'Orleans-Juste P, Souza GE, Rae GA. Endothelin1 -induced ET(A) receptor-mediated nociception, hyperalgesia and

oedema in the mouse hind-paw: modulation by simultaneous ET(B) receptor activation. Br J Pharmacol 2000; 129: 961-68.

Gokin AP, Fareed MU, Pan HL, Hans G, Strichartz GR, Davar G. Local injection of endothelin-1 produces pain-like behavior and excitation of nociceptors in rats. J Neurosci 2001; 21: 5358-66.

[26] Khodorova A, Fareed MU, Gokin A, Strichartz GR, Davar G. Local injection of a selective endothelin-B receptor agonist inhibits endothelin-1 induced pain-like behavior and excitation of nociceptors in a naloxone-sensitive manner. J Neurosci 2002; 22: 7788-96

[27] Khodorova A, Navarro B, Jouaville LS, et al. Endothelin-B receptor activation triggers an endogenous analgesic cascade at sites of peripheral injury. Nat Med 2003; 9: 1055-61.

[28] Menéndez L, Lastra A, Hidalgo A, Baamonde A. Nociceptive reaction and thermal hyperalgesia induced by local ET-1 in mice: a behavioural and fos study. Naunyn-Schmiedebergs Arch Pharmacol 2003; 367: 28-34.

[29] Baamonde A, Lastra A, Villazon M, Bordallo J, Hidalgo A Menendez L. Involvement of endogenous endothelins in thermal and mechanical inflammatory hyperalgesia in mice. Naunyn Schmiedebergs Arch Pharmacol 2004; 369: 245-51.

[30] Da Cunha JM, Rae GA, Ferreira SH, de Chunha Q. Endothelins induce ETB receptor-mediated mechanical hypernociception in rat hindpaw: roles of cAMP and protein kinase C. Eur J Pharmacol 2004; 501: 87-94.

[31] Daher JB, Souza GE, D'Orleans-Juste P, Rae GA. Endothelin ETB receptors inhibit articular nociception and priming induced by carrageenan in the rat knee- joint. Eur J Pharmacol 2004; 496: 7785 .

[32] Houck CS, Khodorova A, Reale AM, Strichartz GR, Davar G. Sensory fibers resistant to the actions of tetrodotoxin mediate nocifensive responses to local administration of endothelin-1 in rats. Pain 2004; 110: 719-26.

[33] Davar G, Hans G, Fareed MU, Sinnott C, Strichartz G. Behavioral signs of acute pain produced by application of endothelin-1 to rat sciatic nerve. Neuroreport 1998; 9: 2279-83.

[34] De-Melo JD, Tonussi CR, D'Orleans-Juste P, Rae GA. Effects of endothelin-1 on inflammatory incapacitation of the rat knee joint. J Cardiovasc Pharmacol 1998a; 31 (Suppl 1): S518-20.

[35] De-Melo JD, Tonussi CR, D'Orleans-Juste P, Rae GA. Articular nociception induced by endothelin-1, carrageenan and LPS in naive and previously inflamed knee-joints in the rat: inhibition by endothelin receptor antagonists. Pain 1998b; 77: 261-69.

[36] Griswold DE, Douglas SA, Martin LD, et al. Endothelin B receptor modulates inflammatory pain and cutaneous inflammation. Mol Pharmacol 1999; 56: 807-12.

[37] Bertelli A, Clerico A, Chicca A, Giovannini L, Gorio A, Romano MA. Role of endothelin-1 in carrageenin-induced inflammation. Int J Tissue React 1992; 14: 225-30.

[38] Maves TJ, Pechman PS, Gebhart GF, Meller ST. Mechanisms of neuropathic pain following chromic gut ligation of the sciatic nerve in the rat. Pain 1993; 54: 57-69.

[39] Klass M, Hord A, Wilcox M, Denson D, Csete M. A role for endothelin in neuropathic pain after chronic constriction injury of the sciatic nerve. Anesth Analg 2005; 101: 1757-62.

[40] Eisenberg E, Vos BP, Strassman AM. The peripheral antinociceptive effect of morphine in a rat model of facial pain Neuroscience 1996; 72: 519-25

[41] Stein C, Gramsch C, Herz A. Intrinsic mechanisms of antinociception in inflammation: local opioid receptors and betaendorphin. J Neurosci 1990; 10: 1292-98.

[42] Hargreaves K, Dubner R, Brown F, Flores C, Joris J. A new and sensitive method for measuring thermal nociception in cutaneous hyperalgesia. Pain 1988; 32: 77-88.

[43] Ren K. An improved method for assessing mechanical allodynia in the rat. Physiol Behav 1999; 67: 711-16.

[44] Anseloni VCZ, Weng H-R, Terayama R, et al. Age- dependency of analgesia elicited by intraoral sucrose in acute and persistent pain models. Pain 2002; 97: 93-103.

[45] Ji R-R, Befort K, Brenner GJ, Woolf CJ. ERK MAP kinase activation in superficial spinal cord neurons induces prodynorphin and NK-1 upregulation and contributes to persistent inflammatory pain hypersensitivity. J Neurosci 2002; 22: 478-85.

[46] Guo W, Zou S, Guan Y, et al. Tyrosine phosphorylation of the NR2B subunit of the NMDA receptor in the spinal cord during the 
development and maintenance of inflammatory hyperalgesia. $\mathbf{J}$ Neurosci 2002; 22: 6208-17.

[47] Iadarola MJ, Douglass J, Civelli O, Naranjo JR. Differential activation of spinal cord dynorphin and enkephalin neurons during hyperalgesia: evidence using cDNA hybridization. Brain Res 1988; 455: 205-12.

[48] Ren K, Hylden J, Williams GM, Ruda MA, Dubner R. The effects of a non-competitive NMDA receptor antagonist, MK-801, on behavioral hyperalgesia and dorsal horn neuronal activity in rats with unilateral inflammation. Pain 1992; 50: 331-44.

[49] Hargreaves K, Flores C, Dionne R, Mueller G. The role of pituitary beta- endorphin in mediating corticotropin-releasing factor-induced antinociception. Am J Physiol 1990; 258: E235-42.

[50] Fareed MU, Hans G, Atanda A, Strichartz G, Davar G. Pharmacological characterization of acute pain behavior produced by application of endothelin-1 to rat sciatic nerve. J Pain 2000; 1: 46-53.

[51] Takai M, Umemura I, Yamasaki K, et al. A potent and specific agonist, Suc-[Glu9,Ala11,15]-endothelin-1(8-21), IRL 1620, for the ETB receptor. Biochem Biophys Res Commun 1992; 184: 95359.

[52] Ishikawa $\mathrm{K}$, Ihara $\mathrm{M}$, Noguchi $\mathrm{K}$, et al. Biochemical and pharmacological profile of a potent and selective endothelin Breceptor antagonist, BQ-788. Proc Natl Acad Sci USA 1994; 91: 4892-96.

[53] Webber KM, Pennefather JN, Head GA, van den Buuse M. Endothelin induces dopamine release from rat striatum via endothelin-B receptors. Neuroscience 1998; 86: 1173-80.

[54] Ishikawa K, Fukami T, Nagase T, et al. Cyclic pentapeptide endothelin antagonists with high ETA selectivity. Potency- and solubility-enhancing modifications. J Med Chem 1992; 35: 213942.

[55] Marsault R, Feolde E, Frelin C. Receptor externalization determines sustained contractile responses to endothelin-1 in the rat aorta. Am J Physiol 1993; 264(3 Pt 1): C687-93.

[56] Ihara M, Yamanaka R, Ohwaki K, et al. [3H]BQ-123, a highly specific and reversible radio-ligand for the endothelin ETA receptor subtype. Eur J Pharmacol 1995; 274: 1-6.

[57] Ihara M, Ishikawa K, Fukuroda T, et al. In vitro biological profile of a highly potent novel endothelin (ET) antagonist BQ-123 selective for the ETA receptor. J Cardiovasc Pharmacol 1992; 20 (Suppl 12): S11-4.
[58] Zhou QL, Strichartz G, Davar G. Endothelin-1 activates ET(A) receptors to increase intracellular calcium in model sensory neurons. Neuroreport 2001; 12: 3853-57.

[59] Zhou Z, Davar G, Strichartz G. Endothelin-1 (ET-1) selectively enhances the activation gating of slowly inactivating tetrodotoxinresistant sodium currents in rat sensory neurons: a mechanism for the pain-inducing actions of ET-1. J Neurosci 2002; 22: 6325-30.

[60] Ossipov MH, Bian D, Malan TP Jr, Lai J, Porreca F. Lack of involvement of capsaicin-sensitive primary afferents in nerveligation induced tactile allodynia in rats. Pain 1999; 79: 127-33.

[61] Mansikka H, Shiotani M, Winchurch R, Raja SN. Neurokinin-1 receptors are involved in behavioral responses to high-intensity heat stimuli and capsaicin- induced hyperalgesia in mice. Anesthesiol 1999; 90: 1643-49.

[62] Mansikka H, Sheth RN, DeVries C, Lee H, Winchurch R, Raja SN. Nerve injury-induced mechanical but not thermal hyperalgesia is attenuated in neurokinin-1 receptor knockout mice. Exp Neurol 2001; 162: 343-49.

[63] Treede RD, Meyer RA, Raja SN, Campbell JN. Peripheral and central mechanisms of cutaneous hyperalgesia. Progr Neurobiol 1992; 38: 397-421.

[64] Motta EM, Calixto JB, Rae GA. Mechanical hyperalgesia induced by endothelin- 1 in rats is mediated via phospholipase $\mathrm{C}$, protein kinase C, and MAP kinases. Exp Biol Med 2006; 231: 1141-45.

[65] Peters CM, Lindsay TH, Pomonis JD, et al. Endothelin and tumorigenic component of bone cancer pain. Neuroscience 2004; 126: 1043-52.

[66] Bax WA, Saxema PR. The current endothelin receptor classification: time for reconsideration? Trends Pharmacol Sci 1994; 15: 379-86.

[67] Yoneyama T, Hori M, Makatani M, et al. Subtypes of endothelin ETA and ETB receptors mediating tracheal smooth muscle contraction. Biochem Biophys Res Commun 1995; 207: 668-74.

[68] Sokolovsky M. Endothelin receptor heterogeneity, G-proteins, and signaling via cAMP and cGMP cascades. Cell Mol Neurobiol 1995; $15:$ 561-71.

[69] Chichorro JG, Zampronio AR, Cabrini DA, Franco CR, Rae GA. Mechanisms operated by endothelin ET(A) and ET(B) receptors in the trigeminal ganglion contribute to orofacial thermal hyperalgesia induced by infraorbital nerve constriction in rats. Neuropeptides 2009; 43: 133-42. doi:10.1016/j.npep. 2008.12.001.

\section{(C) Khodorova et al.; Licensee Bentham Open.}

This is an open access article licensed under the terms of the Creative Commons Attribution Non-Commercial License (http: //creativecommons.org/licenses/by$\mathrm{nc} / 3.0 /$ ), which permits unrestricted, non-commercial use, distribution and reproduction in any medium, provided the work is properly cited. 